\title{
Social and Political Convergence on Environmental Events: The Roles of Simplicity and Visuality in the BP Oil Spill
}

\author{
ANDREAS HOFFBAUER \\ University of Toronto
}

\author{
HOWARD RAMOS \\ Dalhousie University
}

Cet article étudie de quelle façon et à quel moment les journaux, les ONG environnementales, les entreprises privées et le gouvernement convergent autour des événements environnementaux. En utilisant les données sur le déversement de pétrole BP en 2010 tirées des journaux aux États-Unis, au Canada et en Grande-Bretagne et des communiqués de presses de Greenpeace, du Club Sierra, de Halliburton, de Transocean, d'Exxon/Mobil et les annonce de presse de la secrétaire de presse pour le Maison Blanche, nous étudions la capacité d'un événement à faire converger des actions sociales et politiques. En concevant les événements comme des actants, nous vérifions les arguments tirés des publications sur les mouvements sociaux et sur la définition de l'agenda politique à propos du timing, de la simplicité et de la visualité afin de comprendre comment les acteurs politiques convergent. Nous observons que l'effet de convergence est lié au timing, mais pas à la simplicité ou à la visualité.

This paper examines how and when newspapers, environmental nongovernmental organizations, businesses, and the government converge on environmental events. Using data on the 2010 BP Oil Spill from newspaper articles in the United States, Canada, and the United Kingdom, press releases by Greenpeace and Sierra Club, press releases

We would like to thank Paul F. Armstrong, Jim Conley, Mark C.J. Stoddart, and Yoko Yoshida for advice and feedback on earlier drafts of this paper. We are also greatly indebted to the anonymous reviewers and the current and previous editors of the CRS for their suggestions on tightening the focus of the paper. The research was funded by the Social Science and Humanities Research Council of Canada.

Howard Ramos, Department of Sociology and Social Anthropology, Dalhousie University, 6135 University Ave., Rm. 1128 Marion McCain Arts and Social Sciences Bldg., Halifax, Nova Scotia, B3H 4R2 Canada. E-mail: howard.ramos@dal.ca 
by BP, Halliburton, Transocean, ExxonMobil, and Shell, and press statements by the White House Press Secretary, we examine an event's potential to trigger convergence of social and political action. By treating events as political actants, we examine arguments from the agenda-setting and social movement literatures on timing, simplicity, and visuality to understand when political actors converge. We find that convergence is related to temporal cycles but not simplicity or visuality.

ON THE EVENING of April 20, 2010, the Deepwater Horizon offshore drilling platform located in the Gulf of Mexico was rocked by a series of explosions. The accident claimed the lives of 11 workers and after burning uncontrollably for two days the platform sank to the ocean floor. This series of events led to what has become known as "the BP oil spill" and it quickly turned into the largest accidental marine oil spill in history (Robertson and Krauss 2010). To put the disaster into perspective, over 200 million gallons of oil were estimated to have flowed into the Gulf, which is equivalent to 20 Exxon Valdez spills (Steffy 2011). At first, however, the issue was not widely engaged by news media, environmental nongovernmental organizations (ENGOs), oil and industry support companies, or government, and much of the attention paid to the disaster has focused on the economic and legal consequences instead of environmental damage. This is of little surprise to those who track the social and political engagement of environmental harms.

Oil spills are far more common than one might think and most spills gain little attention. In 2010 alone, the same year of the BP oil spill, the U.S. National Oceanic and Atmospheric Administration responded to 60 different oil spills and other incidents (Office of Response and Restoration 2012). In the year before, it responded to 178 oil spills, and the year after 44, showing the regularity of their environmental destruction. Most oil spills, however, do not become the focus of media scrutiny, environmental advocacy, or political intervention. In this paper we ask why this is the case by looking at environmental events as actants that potentially drive convergence of social and political engagement.

\section{LITERATURE REVIEW}

We consider three possible explanations for why social and political actors engage environmental events. The first comes from the agenda-setting literature, which looks at issue attention cycles and feedback loops that drive convergence of social and political action on a given issue (Downs 1972; Henry and Gordon 2001; Hilgartner and Bosk 1988; Peters and Hogwood 1985; Trumbo 1996). According to this literature, timing is important. Most analysis focuses on how problems and the events that drive them become hubs for social and political claims-makers (such as journalists, environmental advocates, businesses, or politicians) to contest power. Hilgartner 
and Bosk (1988) argue that claims-makers cluster around issues, borrowing each other's ideas and information and driving increased rates of public attention through multiple feedback loops that lead to convergence of social and political actors (Dalton et al. 1998; Ungar 1998; Wood and Peake 1998). In essence, if one high-profile claims-maker acts, it triggers the actions of others. This observation aligns with the discursive opportunities, arena, and field analogies used by many social movement scholars (see Ferree et al. 2002; Fligstein and McAdam 2012; Gamson 2007). This leads to our first hypothesis.

H1: Engagement of environmental events is seen in temporal convergences of high-profile claims-makers.

Most scholars in this tradition concentrate on the power and significance of political actors and the political economy of media and advocacy rather than looking at the properties of the events themselves. The political opportunity literature, however, suggest that looking at contextual factors could be useful. It examines how political actors respond to changing social, historical, and political trends (Meyer 2004; Meyer and Minkoff 2004; Ramos 2008). Most of the focus of such research is on institutional structures and how instrumental actors take advantage of them. Murphy (2004) suggests this is a fruitful line of inquiry and shows how environmental disaster can trigger political action. He uses a Latourian approach that treats the environment as an actant. Doing so not only looks at the instrumentality of human political actors, but also considers the role of potential mechanisms of change, which is in line with the mechanisms perspective advocated by McAdam, Tarrow, and Tilly (2001: 24) as well as Charles Tilly (2006). An actant is simply anything that makes other things respond, change, or act (Latour 2007: 54-55). Many scholars looking at environmentalism have adopted this kind of an approach to understand environmental politics and advocacy (see Holifield, Porter, and Walker 2009; Lockie 2004; Stoddart 2011). Essentially this recognizes that both humans and nonhumans can trigger social change. For this reason, we look at the properties of the environmental harms triggered by the $\mathrm{BP}$ oil spill and the weekly events that define it as the impetus for the convergence of social and political reaction.

Macnaghten and Urry (1998) theorize that a person's ability to interpret an environmental problem is limited by their ability to interact with it (see also Mazur 1981; Molotch and Lester 1974, 1975; Wall 1995). When a person is not directly affected by an environmental problem they will be more dependent on third-party information, such as newspaper coverage, press releases by environmental advocacy groups, or statements by companies involved in the problem or political organization tasked with managing environmental problems. Social movement scholars argue that public attention is directed at causes that individuals can translate into their personal experiences (Castells 2004; Gamson 1992). When 
cultural schemas that represent the characteristics and relationships of an issue can be drawn upon, individuals can more easily infer what they are, where they fit in the broader spectrum of life, and what to expect of them (Cerulo 2010:117; D’Andrade 1995; DiMaggio 1997:269). Relatedly, Keck and Sikkink (1998: 27) argue that in order for social problems to gain significant attention they must be converted into "causal stories" that explicitly establish who and what is responsible for the problem. When the actions of specific culprits can be clearly identified, this allows publics to narrow their attention on a specific target (Bennie 1998; Weyler 2004). Causal narratives thus need to be clear and direct in order to gain attention. Shorter, less technical, and less detailed representations of complex issues are necessary for widespread response to a problem (Hilgartner 1990:529; Star 1983).

Complex issues such as climate change or other environmental harms, which have causal narratives with numerous interrelated elements that require technical knowledge, are difficult to understand. Trumbo (1996) notes that scientists play an important role in defining the cause and effect frames of environmental problems but those accounts are often speculative and fraught with uncertainty, and are difficult to interpret (Anderson 2009; Boykoff and Mansfield 2008). As a result, scientific rhetoric can be ambiguous and can be ripe with conflicting information that makes it difficult to define an environmental problem (Futrell 2003:379).

Simpler issues with shorter causal narratives are easier to comprehend and consequently generate more intense reaction by social and political actors (Bennie 1998; Dale 1996; Tsoukas 1999; Young and Dugas 2011). For this reason environmental advocates need to make environmental problems intelligible by increasing their commensurability with existing cultural scripts or schemas. When environmental events are linked in this way they form an effective causal narrative and are more widely engaged (see Cormier and Tindall 2005). We thus ponder the potential of environmental events to elicit simple causal links to harm, which leads to our second hypothesis.

H2: As the potential for an environmental event's causal story to be simplified increases, newspapers, environmental organizations, business and government reactions will converge.

The use of images has long been regarded as a powerful tool in a social movement's arsenal (Halfmann and Young 2010; Rohlinger and Klein 2012:172; Wilkes, Corrigall-Brown, and Myers 2010) and has certainly been important to the environmental movement (Dale 1996; Rootes 2007). A potent image can capture the public's consciousness and transform the way people view their world (DeLuca 1999). Gruesome pictures of seals being slaughtered, aerial photos of vast tracts of deforested land, and oil-covered wildlife have all come to serve this purpose for environmental activism. Environmental issues that have the potential to be 
visually represented through striking images allow audiences to quickly see their severity (Castells 2004:187; Dale 1996; DeLuca 1999; Downs 1972; Ungar 1998; Weingart, Engels, and Pansegrau 2000). In fact, many activists report becoming active in a cause after being exposed to graphic images associated with an issue (Gorney 1998; Shields 2009). This is attributed to the fact that powerful images intensify advocacy frames by providing tangible evidence of a clear victim and physical destruction (Halfmann and Young 2010). In short, they generate causal simplicity.

Images also aid in the processing of information. The human brain is far more adept at extracting information from audio-visual stimuli and absorbing it with greater fidelity than from textual information alone (Graber 1996:86-87). A Pew Research Center for the People and the Press report reveals that 46 percent of American adults find visually based stories easier to interpret and understand (Kohut 2008). Visuals of the Exxon Valdez accident in Prince William Sound, Alaska, played an important role in bringing that disaster to light (Daley and O'Neill 1991). As a result, visuality is quite important.

Not all images, however, are equally potent in evoking moral shock or aiding in making sense of information. Like other forms of informational stimuli, the rhetorical efficacy of an image depends on its salience with an audience's experiential knowledge (Gamson et al. 1992; Graber 1996; Schudson 1989). If images do not resonate with audiences' experiences they will likely be dismissed. This is not to suggest that audiences interpret images homogeneously (Griswold 1987; Milkie 1999; Shively 1992), but rather some images are more recognizable and far reaching than others (Becker 1982, chap. 2; Gamson et al. 1992:375). North American and Western European audiences, for instance, are more likely to draw connections between images of oil-covered pelicans than more abstract environmental harms like holes in the ozone layer.

Striking images that depict destruction have an elevated capacity to emotionally draw observers and trigger moral commitment to act (Calhoun 2004:390-91; Halfmann and Young 2010:19). Allowing images to speak for themselves has likewise been attributed to Greenpeace's success (Dale 1996; Hansen 1993, 2010; Weyler 2004). The more striking an image, the more inclined observers will be to shift their resolve from "this cannot be" to "this must not be" (Halfmann and Young 2010:19). Action-orientated shots and drama in the visuals' frames further act to attract and hold attention by engaging the viewers' emotions (DeLuca 1999:124; Graber 1996:90; Heuer and Reisberg 1990). Mundane and static images by contrast are less gripping and likely to be overlooked by audiences.

Most analysis of such images in the social movement literature, however, tends to focus on the actions of activists to strategically advance campaigns or to conform to dominant media selection biases. This artificially skews analysis from capturing environmental events that are more mundane. Few studies look at the visual potential of environmental harms 
to be captured. For this reason, we change the focus to assess the potential of an environmental event to be visually captured to see if this drives convergence of newspaper, activist advocacy, business, and government response to a potentially harmful environmental event. We hypothesize the following.

\section{H3: Events that can be more easily visually represented are more likely to be engaged by newspapers, advocacy organizations, business, and government.}

In sum, we expect that the reaction to the environmental events of the BP oil spill will converge because of temporal feedback-loops and the potential simplicity of an event's causal narrative and its potential visuality. Less complicated events and those that are easier to portray visually should drive more convergence of social and political actors.

\section{METHODS}

To examine the convergence of news media, environmental advocacy organizations, oil and industry support companies, and the government in response to the $\mathrm{BP}$ oil spill, a new data set consisting of the number of news articles and press releases issued by each is analyzed for the 2010 year. We decided to look at this spill and the events that are associated with it because it is a prominent case and because it is the largest marine disaster in history caused by human error. Each actor's response is aggregated by week. This one-year time frame was selected in order to capture discursive social and political action before and after the explosion on the Deepwater Horizon.

Following many scholars looking at agenda-setting and social movements, the analysis examines news media by counting articles in a number of newspapers. These include the Times-Picayune, New York Times, Wall Street Journal, Globe \& Mail, and Guardian. These venues were selected because they represent a range of local, national, and international news coverage. They also represent differing political orientations. Newspaper response was tracked by counting articles, by publication, which mention the keyword "BP." We decided to use this keyword because it yielded the most hits of relevant material and because we wanted to focus on the BP oil spill and not all oil spills that year. We also conducted additional analyses with other keywords for the same time frame and find similar overall patterns. ${ }^{1}$ Searches were conducted using the Factiva database and results

1. The BP oil spill is also known as "the BP oil disaster," "the Gulf of Mexico oil spill," and the "Macondo blowout," the latter referring to the oil field that the platform was tapping into. By far, the most common reference to the event is "BP oil spill." A hard quote Google search conducted on May 5, 2011 found that it returned 13,300,000 results, compared to 6,560,000,3,170,000, and 25,900 results for the other terms, respectively. For this reason, this is how we refer to the overall events related to the Deepwater Horizon explosion and ensuing oil spill. The resulting analysis would likely have been different had 
were entered by day into a time-series database for the year 2010. Results were then aggregated by week to determine fluctuations and peaks in news media engagement of the $\mathrm{BP}$ oil spill.

We examine ENGOs engaging the BP oil spill by looking at the online press releases of two leading environmental organizations: the Sierra Club and Greenpeace International. Both organizations are household names and for years have been strong advocates of environmental issues. Prior to the BP oil spill, both organizations vigorously campaigned against offshore oil exploration and drilling. They employed distinctly different tactics, making them ideal organizations to compare.

We also look at the online press releases of companies involved in the spill and offshore drilling support. These include the following: BP, Halliburton, Transocean, Shell, and ExxonMobil. All five companies, save for Halliburton and Transocean, have extensive offshore oilfield leases in the Gulf of Mexico and are leading companies in the industry. Halliburton and Transocean are leading providers to offshore oil drilling operations, and both were involved in the preparation of the Macondo well. We decided to look at how companies engaged the incident, to offer a fuller picture of reaction to the accident.

Last, we examine how the White House responded to the incident, by examining the Press Secretary's press statements. The decision to focus on the federal government rather than local or state governments was made because of the scale of the accident and the pressure placed on the White House to coordinate the management of the disaster both domestically and internationally.

Press releases were obtained from online archives of each organization, oil and industry support companies, and the White House. As with newspapers, counts for the keyword were captured by day and then aggregated by week. In the case of BP, all of their press releases for 2010 were captured instead of using the keyword. We decided to use all press releases for this company given its centrality to the spill and to assess the change in the volume of its press engagement before and after the spill. Almost all press statements after the spill mention the disaster in one way or another.

\section{Convergence Scale}

Aggregated weekly data from newspapers, ENGOs, oil and industry support companies, and the White House were then ranked by the top weeks of social and political engagement, listing up to the five most active weeks,

\footnotetext{
1. cont'd other keywords been used, such as those mentioned above; however, to illustrate the most common trends we focus on "BP" because it yielded the most hits and because we wanted to focus on the BP oil spill and not all oil spills. We also conducted analysis for the keyword "Oil Spill" for the same time frame and find similar overall patterns. Results can be made available upon request.
} 
for each actor. This was done to identify points of convergence. Some social or political actors did not have enough variance in their action to offer five distinctive weeks. In those cases their top weeks are reported. Cumulatively, we identified 34 weeks of peak engagement. We next created a convergence scale based on the number of actors engaging in discursive action during the 34 top weeks. The convergence scale is simply a count of the discursive actions of the 13 actors examined. If an actor issued a statement during a top week they were coded as 1 for the given week. A week's score thus reflects the total number of actors issuing at least one press release or statement during a top week. The higher the score, the greater the convergence among the actors. We acknowledge that, because of our choice of keywords, some documents included in the scale contain some noise because of coverage of events other than the oil spill. However, as we explain in footnote ${ }^{1}$, alternate keywords yield similar overall results.

\section{Simplicity and Visuality Scales}

We also coded the environmental events resulting from the Deepwater Horizon explosion and the ensuing oil spill during the 34 top weeks of engagement. We did this with two 5-point scales, one for potential simplicity and the other for potential visuality of environmental events during a top week. We did not code articles or press releases. Instead, data on the environmental events of a given week and their potential was drawn from daily highlights on the New York Times "Tracking the Oil Spill in the Gulf" and CNN's "Oil Spill in the Gulf" webpages. ${ }^{2}$ We took this approach over coding articles or press releases because we wanted to consider temporal context and the potential to offer a simple and visual story of an environmental event irrespective of whether or not actors engaged the week's events. The coding of weeks for each scale was initially done by the first author and then reviewed by the second author until both authors achieved complete intercoder agreement.

On both scales, 0 represented the lowest level of simplicity or visuality and 5 represents the highest level. Table 1 offers detail on the operationalization of the scales.

To give a sense of the simplicity scale coding, in week 37 (September 13-19) when the well was capped in turn stopping the oil spill, all five criteria on the scale were coded yes for a score of 5 out of 5 . During this week it was clear that the oil spill was caused by the faulty blowout preventer (criterion 1), BP was for the most part responsible (criterion 2), and cementing in the well would stop the unabated flow of oil into the Gulf (criterion 3). Using a garden hose as an analogy, audiences could clearly

2. The New York Times Oil Tracker Web page: (http://www.nytimes.com/interactive/2010/05/01/us/ 20100501-oil-spill-tracker.html), the CNN Web page: (http://www.cnn.com/2010/US/05/03/timeline. gulf.spill/index.html). 
Table 1

Simplicity and Visuality Operationalization

\begin{tabular}{|c|c|c|c|}
\hline Concepts & Questions & Range & Focus \\
\hline \multirow[t]{5}{*}{ Simplicity } & $\begin{array}{l}\text { (1) Does the event have } \\
\text { an identifiable } \\
\text { problem? }\end{array}$ & Yes/No & Source of causality \\
\hline & $\begin{array}{l}\text { (2) Does the event have } \\
\text { an identifiable culprit? }\end{array}$ & Yes/No & Actor(s) responsible \\
\hline & $\begin{array}{l}\text { (3) Does the event have } \\
\text { an identifiable } \\
\text { solution? }\end{array}$ & Yes/No & $\begin{array}{l}\text { Proposed plan of } \\
\text { action }\end{array}$ \\
\hline & $\begin{array}{l}\text { (4) Can the problem } \\
\text { associated with the } \\
\text { event be conveyed in a } \\
\text { comprehensible way } \\
\text { without using technical } \\
\text { or advanced concepts } \\
\text { and ideas? }\end{array}$ & Yes/No & $\begin{array}{l}\text { Likelihood of average } \\
\text { audience's ability to } \\
\text { understand } \\
\text { problem* }\end{array}$ \\
\hline & $\begin{array}{l}\text { (5) Can solutions to the } \\
\text { problem associated } \\
\text { with the event or issue } \\
\text { be communicated to } \\
\text { average people without } \\
\text { technical or expert } \\
\text { knowledge? }\end{array}$ & Yes/No & $\begin{array}{l}\text { Likelihood of average } \\
\text { audience's ability to } \\
\text { understand } \\
\text { strategies for } \\
\text { addressing the } \\
\text { problem* }\end{array}$ \\
\hline \multirow[t]{5}{*}{ Visuality } & $\begin{array}{l}\text { (1) Can the focus of the } \\
\text { event be visually } \\
\text { captured by a picture? }\end{array}$ & Yes/No & $\begin{array}{l}\text { Photographic } \\
\text { potential }\end{array}$ \\
\hline & $\begin{array}{l}\text { (2) Can a picture of a } \\
\text { clear victim be taken } \\
\text { during the event? }\end{array}$ & Yes/No & Visibility of victim(s) \\
\hline & $\begin{array}{l}\text { 3) Would pictures of the } \\
\text { event fit an "average } \\
\text { person's" experiential } \\
\text { knowledge? }\end{array}$ & Yes/No & $\begin{array}{l}\text { Likelihood of average } \\
\text { audience's ability to } \\
\text { understand image }\end{array}$ \\
\hline & $\begin{array}{l}\text { (4) Would pictures of the } \\
\text { event offer clear } \\
\text { evidence of physical } \\
\text { destruction? }\end{array}$ & Yes/No & $\begin{array}{l}\text { Visibility of } \\
\text { destruction* }\end{array}$ \\
\hline & $\begin{array}{l}\text { (5) Would a picture of the } \\
\text { event be action } \\
\text { orientated? }\end{array}$ & Yes/No & Context of image \\
\hline
\end{tabular}

*Average audience's ability to understand is operationalized as something that fits within the broader popular consciousness of North American and Western European publics. 
understand what was happening at the seabed and the steps necessary to cap or "plug" the pipe (criteria 4 and 5). An example of the visuality scale coding can be seen in week 16 (April 19-25) when the Deepwater Horizon initially exploded. All five criteria on the scale that week were coded yes. The fire that engulfed the oil platform following the explosion was easily captured on film (criterion 1), clearly depicting a destroyed oil platform and leaking oil (criteria 2 and 4). Moreover, images captured during this week fit common understandings of industrial accidents (criterion 3) and were action orientated with fire flaring uncontrollably and boats and helicopters trying to rescue workers and gain control over it (criterion 5). ${ }^{3}$ Looking at the convergence, simplicity and visuality scales allow us to examine if environmental events have specific properties that draw a wide range of actors into their engagement.

\section{Analysis}

The discursive action of newspapers, ENGOs, oil and industry support companies, and the government can be aggregated in four distinct phases during the 2010 year. They include: a preaccident phase, which occurred between January 1 and April 18, an oil disaster phase that lasted between April 19 and June 20, a capping-the-well phase, between June 21 and August 15, and a normalizing phase beginning on August 16 to the end of the year (for detailed analysis of each phase, see Hoffbauer 2011). Figure 1 identifies those phases and offers an overview of the ebbs and flows of the actor's discursive engagement of the BP oil spill.

Unsurprisingly, Figure 1 shows that the preaccident phase received the least response. This is despite the fact that problems at the site of the Macondo well began as early as 2009 and that during this period BP cut corners to keep costs down and the project on schedule and the Gulf of Mexico experienced a number of oil spills (Bourne 2010:45; Cavnar 2010:27; Freudenburg and Gramling 2011:40). Things began to change, however, when a large gas bubble entered the well's pipe-casing through gaps in the cement around the wellhead and shot up to the Deepwater Horizon platform on April 20th (Bourne 2010:46). This ultimately led to an explosion on the rig killing 11 workers. The ensuing inferno, fed by crude oil and natural gas from the Macondo well, engulfed the rig for two days. On April 22nd, the rig sank after a flotilla of boats unsuccessfully attempted to battle the flames and remotely activate the blowout preventer. These events occurred at the beginning of the oil disaster phase, which Figure 1 shows was the period of greatest reaction. The first actor to discursively engage the disaster was the Times Picayune, then BP, and days later almost

3. An Appendix detailing the events that were coded in the top 34 weeks of engagement is available at http://howardramos.ca/bposp\%20appendix.htm. If you cannot access the site, please contact the second author. 


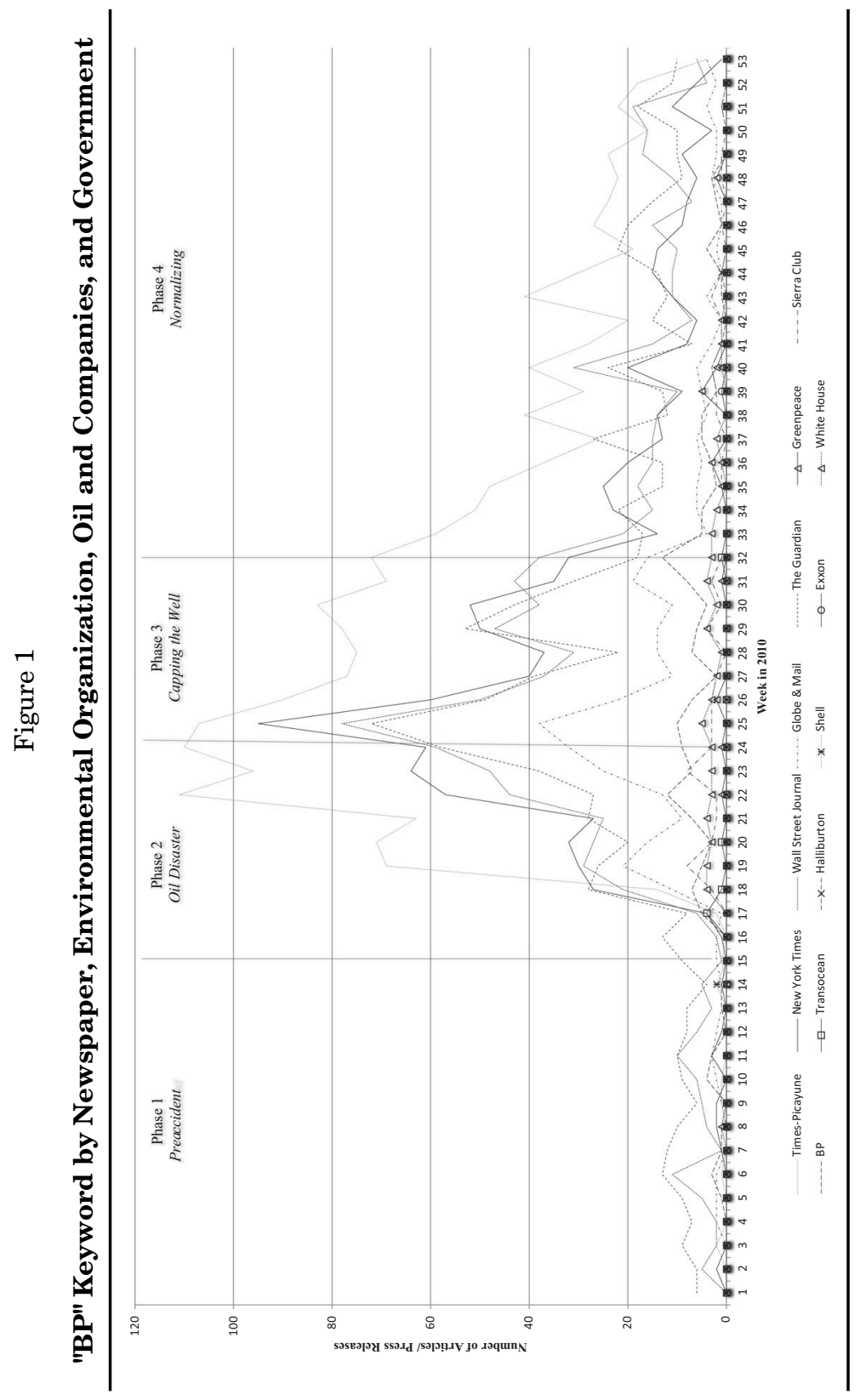


all others, showing convergence and feedback-loops. The explosion had a simple causal narrative and was certainly visible; however, it is unclear whether the environmental harms were similarly acute and perceptible. Repeated efforts to repair the blowout preventer failed during the initial stages of the accident and oil continued to leak into the Gulf of Mexico. This led to a prolonged period during which BP engineers attempted a variety of techniques to stem the flow of oil, leading to what we call the capping-thewell phase. During this period, moments of convergence were also found; however, the simplicity of environmental events and visuality varied. On August 9th, BP announced that its "static kill" operation and cementing procedure were successful and that the Macondo well was finally plugged (Corum et al. 2010). This led to a phase of normalization, where social and political engagement of the oil spill declined steadily. With the Macondo well successfully capped, BP focused all its public relations attention on compensating the victims of the accident and mending its tarnished image. This period had less convergence among social and political actors, and the environmental harms were less clear-cut and visual. The timeline shows mixed support for our hypotheses. As a result, using the preaccident, oil disaster, capping-the-well, and normalizing distinctions, we next look into the BP oil spill in greater detail by comparing weeks of "top engagement" to investigate our hypotheses further.

We begin by looking at convergence in Table 2 . The table ranks the top 34 weeks of engagement by level of convergence among social and political actors. The numbers in the table report on the rank of the top week for different social and political actors. For instance, if the number reported is one, that means that it was the week where the actor published their most articles or press releases. As noted in the Methods section, we look at the top five weeks of actors save for those that have too little variation to look at five weeks.

Week 23, which occurred during the second-last week of the oil disaster phase, saw the most convergence of social and political actors in their top weeks of engagement. Interestingly, this was almost seven weeks after the explosion on the Deepwater Horizon. Nine of the 13 actors examined published an article or issued a press release or statement during that week. Combined, the nine actors published 320 newspaper articles and issued 16 press releases and statements that week. The four actors that did not converge that week were the oil and industry support companies. For most social and political actors week 23 was the second or third most active week of their discursive action. Most actors that week focused on the technical aspects of the disaster and the increasing scale of environmental harms to the Gulf's coastal ecology and wildlife. This is exemplified in the following excerpt from an article published by the New York Times that notes: 


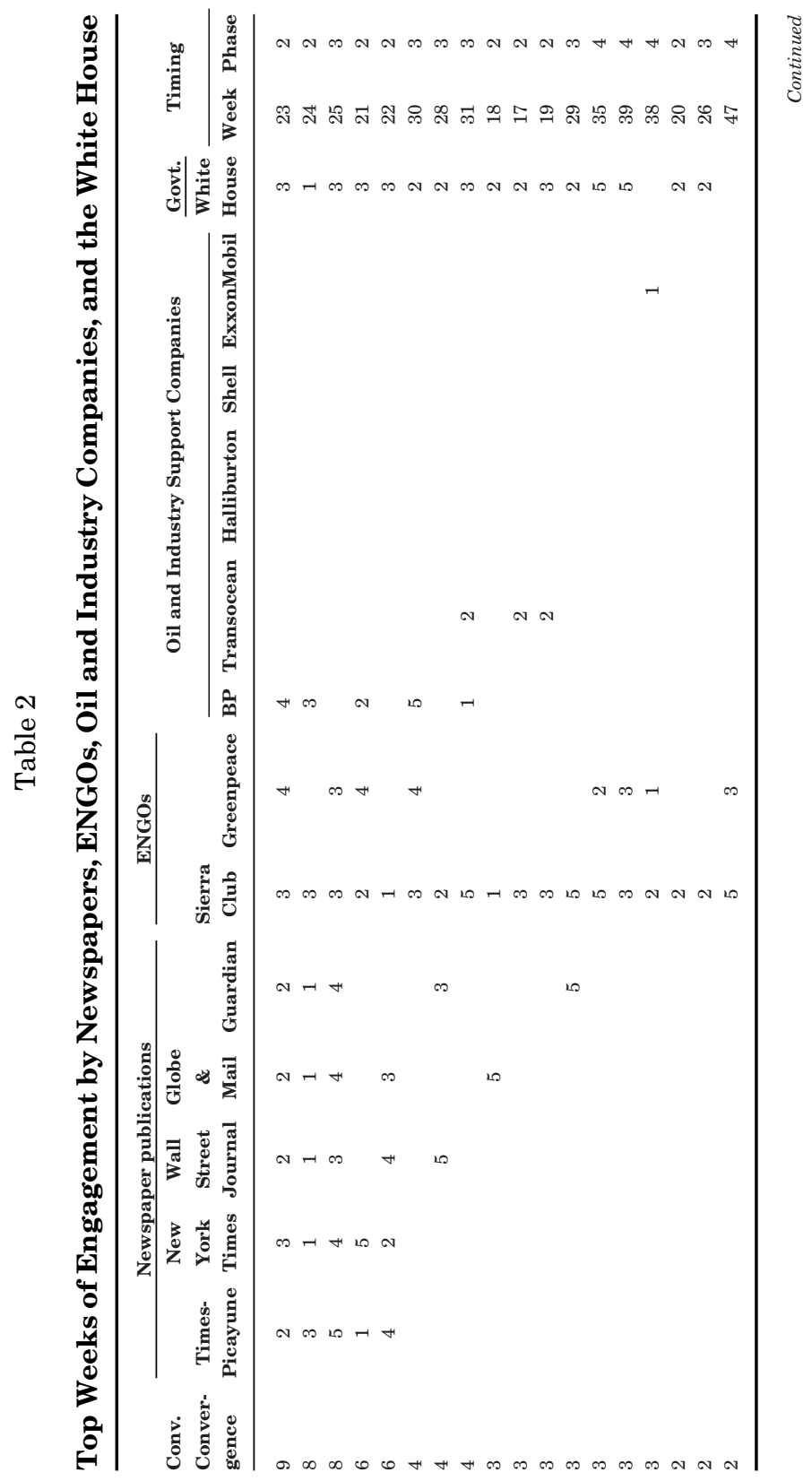


Social and Political Convergence on Environmental Events

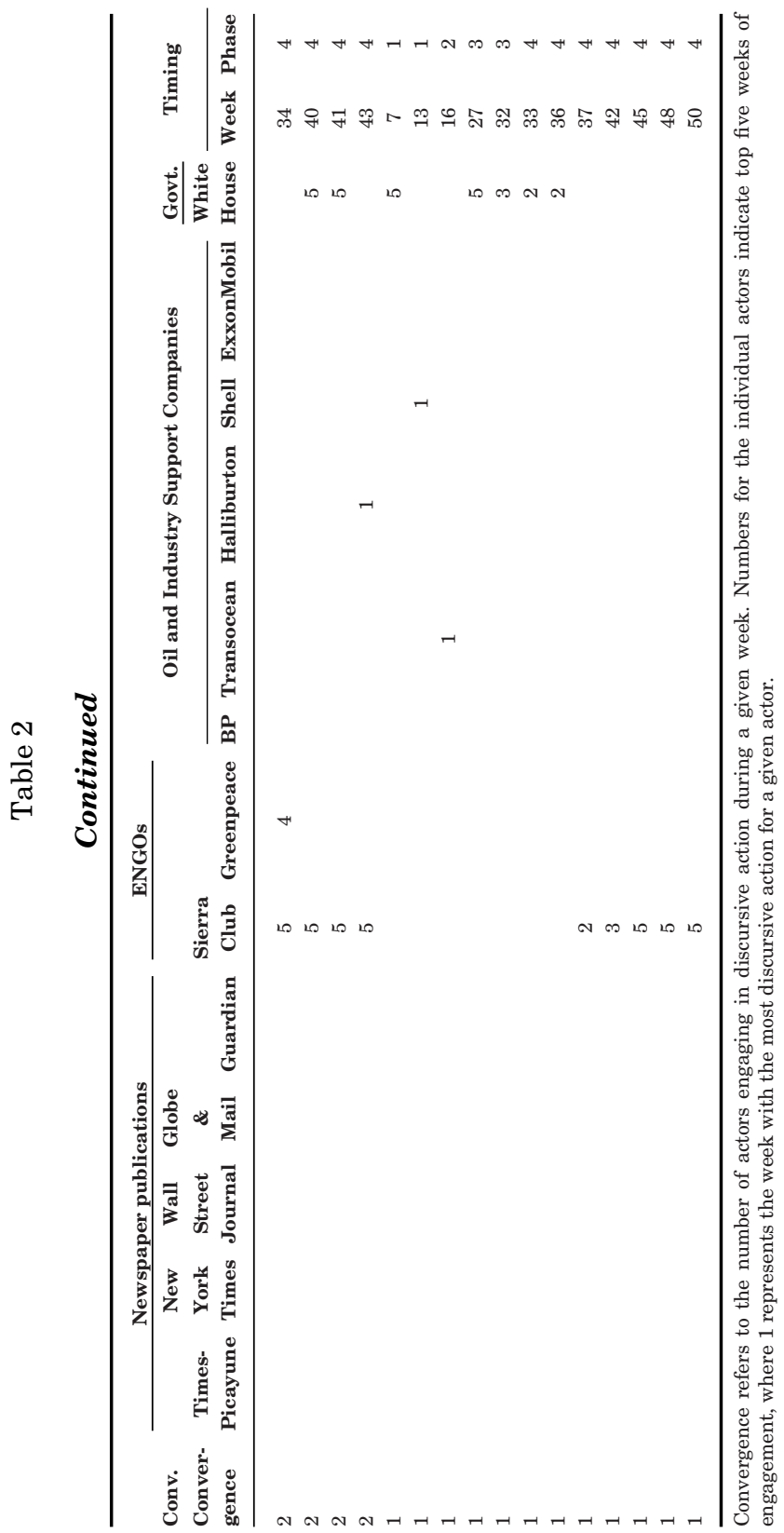


progress in stanching the flow... [but] even if the ultimate strategy - two relief wells - finally succeed in plugging the leak one mile below the surface of the gulf, it would take "well into the fall" to clean up the beaches and marshes sullied by the oil and to address other environmental harm. (Krauss 2010)

Such reaction was common across newspapers, as well as the ENGOs and the White House. By contrast, the week of the Deepwater Horizon explosion received the least convergence in terms of top weeks of engagement. During week 16, Transocean was the only actor to have a top week of engagement. In fact, it was Transocean's number one week of discursive action on the spill. During that week most engagement was speculative, which can be seen in a press release issued by Transocean:

The combined response team was not able to stem the flow of hydrocarbons prior to the rig sinking, and we are working closely with BP Exploration \& Production, Inc. and the U.S. Coast Guard to determine the impact from the sinking of the rig and the plans going forward. The U.S. Coast Guard has plans in place to mitigate any environmental impact from this situation. (Transocean 2010)

Surprisingly, the events during this week did not generate enough action by the newspapers, ENGOs, or the White House to be considered one of their top weeks of discursive action. In total, Transocean issued four press releases that week focusing on remotely activating the blowout preventer and stopping the leakage of oil into the Gulf. This is a far cry from the reaction and convergence generated in week 23 .

As a whole, Table 2 illustrates what most agenda-setting and social movement scholars would expect. Convergence of social and political actors during the peak moments of discursive action largely occurs in clusters of feedback-loops where actors respond to one another. For newspapers, ENGOs and the White House this largely occurred during the oil disaster and capping-the-well phases. The only exceptions are the oil and industry support companies that were more active in the normalizing phase and conspicuously silent during the peak of the disaster. Much of their discursive action was geared to reassuring the public that the industry learned from the disaster and to project a positive image of offshore oil production. ExxonMobil's Lloyd Guillory demonstrates this in a press release during this phase by noting the following:

We are working quickly and effectively in an unprecedented effort to improve incident preparedness. Our progress since we announced the system demonstrates the commitment of our companies to make equipment immediately available for incident response. (ExxonMobil 2010)

Not surprisingly, it appears that the oil and industry support companies focused on preserving their industry rather than the environment. 
Table 3

Simplicity and Visuality Scores by Convergence

\begin{tabular}{|c|c|c|c|c|}
\hline Convergence & Simplicity & Visuality & Week & Phase \\
\hline 9 & 3 & 3 & 23 & 2 \\
\hline 8 & 2 & 2 & 24 & 2 \\
\hline 8 & 3 & 3 & 25 & 3 \\
\hline 6 & 3 & 3 & 21 & 2 \\
\hline 6 & 3 & 3 & 22 & 2 \\
\hline 4 & 3 & 0 & 28 & 3 \\
\hline 4 & 3 & 0 & 30 & 3 \\
\hline 4 & 3 & 3 & 31 & 3 \\
\hline 3 & 3 & 3 & 17 & 2 \\
\hline 3 & 3 & 4 & 18 & 2 \\
\hline 3 & 3 & 3 & 19 & 2 \\
\hline 3 & 3 & 0 & 29 & 3 \\
\hline 3 & 3 & 3 & 35 & 4 \\
\hline 3 & 1 & 0 & 38 & 4 \\
\hline 3 & 2 & 0 & 39 & 4 \\
\hline 2 & 3 & 4 & 20 & 2 \\
\hline 2 & 1 & 4 & 26 & 3 \\
\hline 2 & 4 & 4 & 34 & 4 \\
\hline 2 & 2 & 2 & 40 & 4 \\
\hline 2 & 2 & 0 & 41 & 4 \\
\hline 2 & 3 & 0 & 43 & 4 \\
\hline 2 & 3 & 4 & 47 & 4 \\
\hline 1 & 0 & 0 & 7 & 1 \\
\hline 1 & 0 & 0 & 13 & 1 \\
\hline 1 & 1 & 5 & 16 & 2 \\
\hline 1 & 3 & 4 & 27 & 3 \\
\hline 1 & 3 & 0 & 32 & 3 \\
\hline 1 & 3 & 0 & 33 & 4 \\
\hline 1 & 2 & 0 & 36 & 4 \\
\hline 1 & 5 & 3 & 37 & 4 \\
\hline 1 & 5 & 0 & 42 & 4 \\
\hline 1 & 2 & 0 & 45 & 4 \\
\hline 1 & 1 & 0 & 48 & 4 \\
\hline 1 & 3 & 0 & 50 & 4 \\
\hline
\end{tabular}

Convergence refers to the number of actors engaging in discursive action during a given week. Simplicity and complexity refer to scales where 5 means the simplest and/or most visual.

Next, in Table 3, we consider whether or not convergence of social and political actors is tied to the potential of environmental events' causal narrative simplicity and visuality. Table 3 shows that environmental events during the top week of convergence, week 23, scored 3 out of 5 on both the simplicity and visuality scales. During that week, the potential problems associated with environmental harms were clear, the culprits were 
identifiable, and with oil washing up on beaches there was no technical knowledge needed to understand what the problem was. Sierra Club used powerful examples of how the oil spill had affected the gulf's ecology and demanded that BP be held fully responsible for the response efforts and the ecological recovery of the region. This can be seen in a press release issued by Sierra Club two weeks after the blowout, which argued the following:

We are already watching wildlife like sea turtles and birds washing up on beaches and we can expect things to get much worse. Recovery and rescue of marine life and habitat will likely take decades. (Sierra Club 2010)

As the language evoked illustrates, there were simple stories but there was also much potential for visuals of the environmental damage. By contrast, during the week of the initial accident, week 16 , there was little convergence, and ambiguity surrounded the events and environmental harms. All of the parties involved were grappling with understanding what had happened. That week the potential to offer a simple causal narrative was low, with a score of only 1 out of 5 on the simplicity scale. Yet, despite the ambiguity surrounding the initial accident, there was no shortage of potentially striking images. In fact, that week received the highest score, 5 out of 5 , on the visuality scale. The problem on the rig was clearly depicted by vivid images of the inferno. With the rig crippled by the blaze, there was a clear victim and signs of physical destruction and potential environmental harm. The data in Table 3 appear to offer some support for the importance of the potential simplicity of an environmental event's causal narrative; however, the potential of its visuality is less clear-cut.

To examine this further, in Table 4 we look at correlations among convergence and the potential for simplicity and visuality as well as week and phase. When this is done, we see that simplicity and visuality are positively correlated with convergence, though visuality has a greater correlation than simplicity. However, neither set of relations is statistically significant, countering our expectations. When convergence is correlated with week and phase we see that it has a negative and statistically significant relationship-showing that timing and response to other social and political actors seem to matter more than the properties of an environmental harm. It also means that social and political actors were more likely to act discursively in the earlier weeks and phases of the disaster.

To examine the relationship between convergence and phase further, we also examined the average levels of convergence, simplicity, and visuality across phases. To test statistical significance we use $t$-tests of differences of means for each factor in a given phase compared against means in phase four as the reference group. When this is done we see that the average level of convergence decreases over time. It is highest in the oil disaster phase (2) and lowest in the preaccident and normalizing phases ( 1 and 4$)$. The same is seen with visuality. The differences of means across 
Table 4

\section{Correlations and $t$-Tests of Means for Convergence, Simplicity, Visuality, Week, and Phase}

\begin{tabular}{lccccc}
\hline Correlations & Convergence & Simplicity & Visuality & Week & Phase \\
\hline Convergence & - & & & \\
Simplicity & .14 & - & & \\
Visuality & .25 & .22 & - & & \\
Week & $-.30^{*}$ & .27 & $-.38^{* *}$ & - & \\
Phase & $-.34^{* *}$ & $.32^{* *}$ & $-.30^{*}$ & $.93^{* * * *}$ & - \\
$t$-Tests of means & & & & & \\
$\quad$ Phase 1 & 1 & $0^{* *}$ & 0 & \\
Phase 2 & $.56^{* * *}$ & .67 & $.33^{* * * *}$ & \\
Phase 3 & $.38^{* * *}$ & .75 & .75 & \\
Phase 4 (Ref.) & .73 & .73 & .07 & \\
\hline
\end{tabular}

$* p<.10 ; * * p<.05 ; * * * p<.01$.

phases for both are statistically significant. The average level of simplicity across phases is more balanced and is not significant. The correlations and differences of means show that, as the disaster moved from environmental harms in the earlier phases and weeks to economic problems in the normalizing period, convergence decreased. It also shows that much of the engagement was from social and political actors responding to one another.

In fact, much of the discursive engagement of the spill after the well was capped was not about its environmental harms, but rather its social and economic consequences. This can be seen in White House Press Secretary Robert Gibbs's response to a reporter's question pertaining to the size of BP's escrow account:

What's important to the President as it relates to the claims process is that they're handled fairly, promptly, and that BP has enough money to make these folks whole who have been hurt so much by the spill. (White House 2010)

The focus was on the legal and economic aspects of the spill, barely recognizing its environmental impact.

\section{CONCLUSION}

The explosions on the Deepwater Horizon set in motion a series of environmental events that captured the attention of newspapers, ENGOs, oil and industry support companies, and government for much of 2010. Even so, just a year later, BP's profits increased 16 percent (Associated Press 2011) 
and 69 percent of Americans favor increased offshore drilling, the highest rate since the summer of 2008 (Walsh 2011). In this paper we treated the environmental events that followed the explosion as actants, to see how they shaped the social and political convergence to the oil spill. We examined the role of temporality and analyzed if convergence around the oil spill's environmental events were dependent on their potential simplicity of causal narrative and their visuality.

Tabular and graphical analysis suggests that social and political actors responded to one another in feedback loops when engaging the environmental harms of the BP oil spill. The same analysis also shows that potential simplicity of causal narratives and visuality of environmental events play a partial role in when social and political actors engage environmental harms. Newspapers, ENGOs, and the White House all had the most discursive action relating to the spill during times when the dangers of the spill were most pressing. However, that period was also when causal simplicity of environmental harms was most ambiguous. It was only as the oil spill grew larger and more reflection was offered that potential simplicity increased. At that point the oil and industry support companies became more active. At that time the spill moved from an environmental disaster to an economic hardship. Newspapers, ENGOs, and the White House also converged when the environmental dangers of the oil spill had the most potential to be portrayed visually. The oil and industry support companies during this period were conspicuously silent. As the potential visuality of environmental harms decreased after the capping of the Macondo well, the oil and industry support companies had more discursive action. Save for the local newspaper, other social and political actors were more sporadic in their engagement of the environmental harms. When these trends were tested statistically, however, only temporal factors relating to phase of the oil spill or week of engagement were statistically significant with convergence. The potential for causal narrative simplicity and visuality were not statistically significant in their correlation with convergence of discursive action. Convergence appears to have less to do with environmental events' properties than with social and political actors. The BP oil spill moved from being framed as an environmental disaster to economic devastation of communities.

Overall our research offers some insight into how social and political actors respond to environmental harms and why environmental events, despite posing substantial threats to the earth's ecology and human wellbeing, are largely sporadically engaged by newspapers, ENGOs, businesses that cause them, and politicians. At the end of the day, treating environmental events as actants shows that most social and political actors do not respond to the properties of environmental harms but, instead, to other social and political factors. Until this changes, the environment will silently suffer. 


\section{References}

Anderson, A. 2009. "Media, Politics and Climate Change: Towards a News Research Agenda." Sociology Compass 3(2):166-82.

Associated Press. 2011. "BP Profits Rise, Expects Gulf Drilling to Resume." CBS News, April 27. Retrieved May 9, 2011 (http://www.cbsnews.com/stories/2011/04/27/national/ main20058048.shtml).

Becker, H. 1982. Art Worlds. Berkeley, CA: University of California Press.

Bennie, L.G. 1998. "Brent Spar, Atlantic Oil and Greenpeace." Parliamentary Affairs 51(3):397410.

Bourne, J. 2010. “Is Another Deepwater Disaster Inevitable?" National Geographic 218(4):2861.

Boykoff, M.T. and M. Mansfield. 2008. "Ye Olde Hot Aire: Reporting on Human Contributions to Climate Change in the UK Tabloid Press." Environmental Research Letters 3:1-8.

Calhoun, C. 2004. "A World of Emergencies: Fear, Intervention, and the Limits of Cosmopolitan Order." Canadian Review of Sociology 41(4):373-95.

Castells, M. 2004. The Power of Identity. Malden, MA: Blackwell Publishing.

Cavnar, B. 2010. Disaster on the Horizon: High Stakes, High Risk, and the Story Behind the Deepwater Well Blowout. White River Junction, VT: Chelsea Green Publishing.

Cerulo, K. 2010. "Mining the Intersection of Cognitive Sociology and Neuroscience." Poetics 38:115-32.

Cormier, J. and D. B. Tindall. 2005. "Wood Frames: Framing the Forests in British Columbia." Sociological Focus 38(1):1-24.

Corum, J., A. Granberg, M. Gronhahl, Xaquin G.V., H. Park, S. Pecanha and G. Roberts. 2010. "Methods That Have Been Tried to Stop the Leaking Oil." The New York Times. Retrieved February 1, 2011 (http://www.nytimes.com/interactive/2010/05/25/us/20100525topkill-diagram.html).

Dale, S. 1996. McLuhan's Children: The Greenpeace Message and the Media. Toronto, ON: Between the Lines.

Daley, P. and D. O’Neill. 1991. "Sad is too Mild a Word: Press Coverage on the Exxon Valdez Oil Spill." Journal of Communication 41(4):42-57.

Dalton, R.J., P.A. Beck, R. Huckfeldt and W. Koetzle. 1998. "A Test of Media-Centered Agenda Setting: Newspaper Content and Public Interest in a Presidential Election." Political Communication 15(4):463-81.

D'Andrade, R. 1995. The Development of Cognitive Anthropology. Cambridge, MA: Cambridge University Press.

DeLuca, K.M. 1999. Image Politics: The New Rhetoric of Environmental Activism. New York, NY: The Guilford Press.

DiMaggio, P. 1997. "Culture and Cognition.” Annual Review of Sociology 23:263-87.

Downs, A. 1972. "Up and Down with Ecology: The 'Issue-Attention Cycle' Dynamics of the Public Agenda." The Public Interest 28(Summer):38-50.

ExxonMobil. 2010. "ExxonMobil Announces Equipment for Industry Use through Marine Well Containment Company." Retrieved November 25, 2010 (http://www.businesswire.com/ portal/site/exxonmobil/index.jsp?ndm...news_viewandnmConfigId=1001106andnewsId= 20100920006909andnewsLang=en). 
Ferree, M.M., W.A. Gamson, J. Gerhards and D. Rutch. 2002. Shaping Abortion Discourse: Democracy and the Public Sphere in Germany and the United States. New York: Cambridge University Press.

Fligstein, N. and D. McAdam. 2012. A Theory of Fields. New York, NY: Oxford University Press.

Freudenburg, W.R. and R. Gramling. 2011. Blowout in the Gulf: The BP Oil Spill Disaster and the Future of Energy in America. Cambridge, MA: MIT Press.

Futrell, R. 2003. "Framing Processes, Cognitive Liberation, and NIMBY Protest in the U.S. Chemical-Weapons Disposal Conflict.” Sociological Inquiry 73(3):359-86.

Gamson, W. 1992. Talking Politics. New York, NY: Cambridge University Press.

Gamson, W., D. Croteau, W. Hoynes and T. Sasson. 1992. "Media Images and the Social Construction of Reality." Annual Review of Sociology 18:373-93.

Gamson, W.A. 2007. "Bystander, Public Opinion, and the Media" Pp. 242-61 in The Blackwell Companion to Social Movements, edited by D.A. Snow, S.A. Soule and H. Kriesi. Malden, MA: Blackwell.

Gorney, C. 1998. Articles of Faith: A Frontline History of the Abortion Wars. New York, NY: Simon and Schuster.

Graber, D.A. 1996. Mass Media and American Politics. 5th ed. Washington, DC: CQ Press.

Griswold, W. 1987. "The Fabrication of Meanings: Literary Interpretation in the United States, Great Britain, and the West Indies." American Journal of Sociology 92(5):1077-117.

Halfmann, D. and M. Young. 2010. "War Pictures: The Grotesque as a Mobilizing Tactic." Mobilization 15(1):1-24.

Hansen, A. 1993. The Mass Media and Environmental Issues. Leicester: Leicester University Press.

Hansen, A. 2010. Environment, Media and Communication. London: Routledge.

Henry, G.T. and C.S. Gordon. 2001. "Tracking Issue Attention: Specifying the Dynamics of the Public Agenda." Public Opinion Quarterly 65(2):157-77.

Hilgartner, S. 1990. "The Dominant View of Popularization: Conceptual Problems, Political Uses." Social Studies of Science 20(3):519-39.

Hilgartner, S. and C.L. Bosk 1988. "The Rise and Fall of Social Problems: A Public Arenas Model." American Journal of Sociology 94(1):53-78.

Hoffbauer, A. 2011. "Beyond the Deepwater Horizon Explosion: What Shaped the Social and Political Engagement of the BP Oil Spill?" Master's thesis, Dalhousie University, Halifax, NS.

Holifield, R., M. Porter and G. Walker. 2009. "Spaces of Environmental Justice: Frameworks for Critical Engagement." Antipode 41(4):591-612.

Keck, M.E. and K. Sikkink. 1998. Activist Beyond Borders. Ithaca, NY: Cornell University Press.

Kohut, A. 2008. "Key News Audiences Now Blend Online and Traditional Sources: Audience Segments in a Changing News Environment." Pew Research Center (August 17). Retrieved June 6, 2011 (http://people-press.org/2008/08/17/key-news-audiences-now-blendonline-and-traditional-sources).

Krauss, C. 2010. "Cap Said to Recover 10,000 Barrels of Oil a Day.” The New York Times, June 7.

Latour, B. 2007. Reassembling the Social: An Introduction to Actor-Network-Theory. New York: Oxford University Press. 
Lockie, S. 2004. "Collective Agency, Non-Human Causality and Environmental Social Movements: A Case Study of the Australian 'Landcare Movement." Journal of Sociology 40(1):41-57.

Macnaghten, P. and J. Urry. 1998. Contested Natures. Thousand Oaks, CA: Sage Publications.

Mazur, A. 1981. "Media Coverage and Public Opinion on Scientific Controversies." Journal of Communication 31(2):106-15.

McAdam, D., S. Tarrow and C. Tilly. 2001. Dynamics of Contention. New York: Cambridge University Press.

Meyer, D.S. 2004. "Protest and Political Opportunities." Annual Review of Sociology 30:125-45.

Meyer, D.S. and D.C. Minkoff. 2004. "Conceptualizing Political Opportunity." Social Forces 82(4):1457-92.

Milkie, M. 1999. "Social Comparisons, Reflected Appraisals, and Mass Media: The Impact of Pervasive Beauty Images on Black and White Girls' Self-Concepts." Social Psychology Quarterly 62(2):190-210.

Molotch, H. and M. Lester. 1974. "News as a Purposive Behavior: On the Strategic Use of Routine Events, Accidents, and Scandals." American Sociological Review 39:101-12.

Molotch, H. and M. Lester. 1975. "Accidental News: The Great Oil Spill as Local Occurrence and National Event." American Journal of Sociology 81(2):235-60.

Murphy, R. 2004. "Disaster or Sustainability: The Dance of Human Agents with Nature's Actants." Canadian Review of Sociology 41(3):249-66.

Office of Response and Restoration. 2012. "Incident Map." Incidence News. Retrieved September 6, 2012 (http://incidentnews.noaa.gov/map).

Peters, B.G. and B.W. Hogwood. 1985. "In Search of the Issue-Attention Cycle." The Journal of Politics 47(1):238-53.

Ramos, H. 2008. "Opportunity for Whom?: Political Opportunity and Critical Events in Canadian Aboriginal Mobilization, 1951-2000." Social Forces 87(2):795-823.

Robertson, C. and C. Krauss. 2010. "Gulf Spill is the Largest of its Kind, Scientists Say." The New York Times, August 2. Retrieved May 9, 2011 (http://www. nytimes.com/2010/08/03/us/03spill.html? $\mathbf{r}=1$ andfta=yandpagewanted=print).

Rohlinger, D.A. and J. Klein. 2012. "Visual Landscapes and the Abortion Issue." American Behavioural Scientist 56(2):172-88.

Rootes, C. 2007. "Environmental Movements." Pp. 608-40 in The Blackwell Companion to Social Movements, edited by D.A. Snow, S.A. Soule and H. Kriesi. Malden, MA: Blackwell.

Schudson, M. 1989. “The Sociology of News Production." Media, Culture and Society 11(3):26382.

Shields, J.A. 2009. The Democratic Virtues of the Christian Right. Princeton, NJ: Princeton University Press.

Shively, J. 1992. "Cowboys and Indians: Perceptions of Western Films among American Indians and Anglos." American Sociological Review 57(6):725-34.

Sierra Club. 2010. "Sierra Club: Will BP Pay for Lost Jobs, Decades of Costal Recovery?" Retrieved August 31, 2011 (http://action.sierraclub.org/site/MessageViewer?em id $=175181.0$ ).

Star, S.L. 1983. "Simplification in Scientific Work: An Example from Neuroscience Research." Social Studies of Science 13(2):205-28. 
Steffy, L. 2011. Drowning in Oil: BP and the Reckless Pursuit of Profit. New York, NY: McGrawHill.

Stoddart, M.C.J. 2011. "Grizzlies and Gondolas: Animals and the Meaning of Skiing Landscapes in British Columbia, Canada." Nature and Culture 6(1):41-63.

Tilly, C. 2006. Why: What Happens When People Give Reasons... and Why? Princeton, NJ: Princeton University Press.

Transocean. 2010. "Transocean Ltd. Provides Updates on Semisubmersible Drilling Rig Deepwater Horizon.” Retrieved August 31, 2011 (http://phx.corporateir.net/phoenix.zhtml?c=113031\&p=irol-newsArticle_print\&ID=1416100\&highlight=).

Trumbo, C. 1996. "Constructing Climate Change: Claims and Frames in US News Coverage of an Environmental Issue." Public Understanding of Science 5(3):269-83.

Tsoukas, H. 1999. "David and Goliath in the Risk Society: Making Sense of the Conflict between Shell and Greenpeace in the North Sea." Organization 6(3):499-528.

Ungar, S. 1998. "Bringing the Issue Back In: Comparing the Marketability of the Ozone Hole and Global Warming." Social Problems 45(4):510-27.

Wall, G. 1995. "Barriers to Individual Environmental Action: The Influence of Attitudes and Social Experience." Canadian Review of Sociology 32(4):465-89.

Walsh, B. 2011. "The BP Oil Spill, One Year On: Forgetting the Lessons of Drilling in the Gulf." Time, April 20. Retrieved May 5, 2011 (http://www.time.com/time/ health/article/0,8599,2066233,00.html).

Weingart, P., A. Engels and P. Pansegrau. 2000. "Risks of Communication: Discourses on Climate Change in Science, Politics, and the Mass Media." Public Understanding of Science 9(3):261-83.

Weyler, R. 2004. Greenpeace: The Inside Story. Vancouver, BC: Raincoast Books.

White House. 2010. "Press Gaggle by Deputy Press Secretary Bill Burton en Route Andrews Air Force Base." Retrieved November 25, 2010 (http://www.whitehouse.gov/thepress-office/press-gaggle-deputy-press-secretary-bill-burton-en-routeandrews-air-forcebase-615).

Wilkes, R., C. Corrigall-Brown and D.J. Myers. 2010. "Packaging Protest: Media Coverage of Indigenous People's Collective Action Packaging Protest." Canadian Review of Sociology 47(4):327-57.

Wood, B.D. and J.S. Peake. 1998. "The Dynamics of Foreign Policy Agenda Setting." American Political Science Review 92(1):173-84.

Young, N. and E. Dugas. 2011. "Representations of Climate Change in Canadian National Print Media: The Banalization of Global Warming." Canadian Review of Sociology 48(1):1-22. 